\title{
Experimental Electric Retrofitting of an Ice Vehicle with Simulation and Cost Analysis
}

\author{
Ashish Rajeshwar Kulkarni, Sudhanshu Singh, Krishan Kant, Hemant Bharti
}

\begin{abstract}
With increasing awareness towards environmental issues, the modern society seems inclined towards use of cleaner fuel in transportation and a drift towards electric vehicles is now being observed world over. Government of India has already made its vision 2030 public in which $100 \%$ use of electric vehicles in public transport and increased percentage of electric vehicles in personal passenger vehicles is envisaged. The paper presents a method followed for the conversion process of a traditional ICE vehicle to electric vehicle. The research specifically takes into consideration ARAI guidelines and Indian laws that benefit the process. The paper is presented in three sections. The first section deals with essential electrical components required for the procedure and their selection respectively. The second section contains simulation of selected electric motor along with cost analysis of the complete drive. The third section contains the procedure followed to obtain the final vehicle along with descriptive images for better understanding of placement of the components. The final vehicle obtained is highly cost effective as well as efficient in its performance.
\end{abstract}

Keywords: BLDC, Conversion, Gearbox, Retrofitting.

\section{INTRODUCTION}

With more than 13 million vehicles already in Delhi[1]; manufacturing of new vehicles would only add to the problem. The electric cars utilize large battery packs for storage of energy which increases the already inflated cost of a new car. Hence retrofitting plays an important role and changes the already existing power-train of the vehicle.

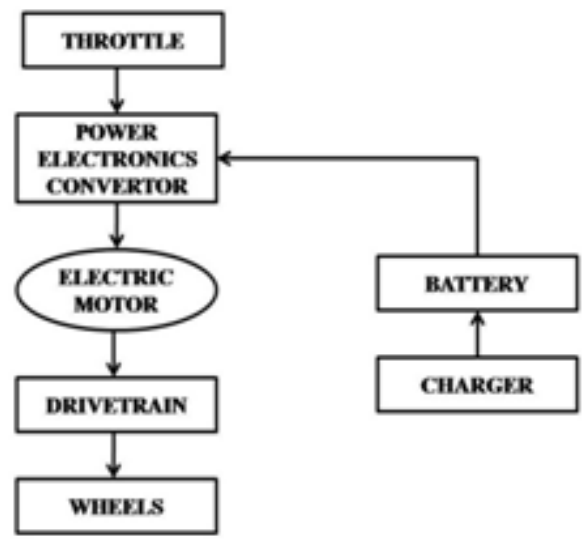

Figure.1. Block diagram of drive train in electric vehicle The main objective of the project involves parameter calculation for selection of electric vehicle's motor and

Revised Manuscript Received on July 05, 2020.

Ashish Rajeshwar Kulkarni, Assistant Professor, Department of Electrical, Technological University, Delhi. India.

Sudhanshu Singh, B.Tech, Department of Electrical Engineering, Technological University, Delhi. India.

Krishan Kant, B.Tech, Department of Electrical Engineering, Technological University, Delhi. India.

Hemant Bharti, B.Tech, Department of Electrical Engineering, Technological University, Delhi. India. comparative analysis of selected motor with alternatives available and final cost comparison between ICE vehicles with the retrofitted vehicle. From Yedamale P. [2] paper on bldc drives, the characteristics and performance of bldc motor was understood for analysis along with Howe's paper [3] steps for simulation following comparative analysis using torque-speed curves of different drives in EV. From the many available models the mathematical modelling and simulation was selected due to its flexibility [4]. For understanding the conventional procedure of manufacturing EV,different methods were studied,which offered a more mechanical perspective [5][6].

\section{MOTOR PARAMETERS CALCULATION BASED ON VEHICLE DYNAMICS}

Vehicle dynamics basic principles can be used to study the behaviour of the vehicle under given circumstances, primarily focusing on friction offered by road, its inclination and the aerodynamic drag playing on the vehicle.

Table.1. Vehicle Specification

\begin{tabular}{|l|l|}
\hline Vehicle data & Values \\
\hline Vehicle weight & $750 \mathrm{~kg}$ \\
\hline Seating capacity & 8 \\
\hline No. of gears & 4 Forward, 1 Reverse \\
\hline First gear & 3.721 \\
\hline Second gear & 2.289 \\
\hline Third gear & 1.947 \\
\hline Fourth gear & 1.000 \\
\hline Wheel radius & $253 \mathrm{~mm}$ \\
\hline Passanger weight(assumed) & $70 \mathrm{~kg}(\mathrm{each})$ \\
\hline Width \& height & $1410 \mathrm{~mm}, 1640 \mathrm{~mm}$ \\
\hline
\end{tabular}

Table.2. Motor Parameter Calculation

\begin{tabular}{|c|c|}
\hline Motor data & Values \\
\hline Weight (vehicle +8 people) & $1310 \mathrm{~kg}$ \\
\hline Wheel radius & $253 \mathrm{~mm}$ \\
\hline Gear ratio (first gear) & 3.7 \\
\hline Vehicle speed(desired) & $40 \mathrm{kmph}$ \\
\hline Rolling coefficient & 0.018 \\
\hline Drag coefficient & 0.4 \\
\hline Front area $\left(\mathrm{m}^{2}\right)$ & \\
\hline
\end{tabular}




\section{Experimental Electric Retrofitting of an Ice Vehicle with Simulation and Cost Analysis}

\begin{tabular}{|l|l|}
\hline Road inclination(degree) & 15 \\
\hline Air resistance & $69.63 \mathrm{~N}$ \\
\hline Rolling resistance & $232.084 \mathrm{~N}$ \\
\hline Gradient resistance & $59.78 \mathrm{~N}$ \\
\hline Total resistance & $360.5 \mathrm{~N}$ \\
\hline Wheel torque required & $91.2 \mathrm{Nm}$ \\
\hline Motor torque required & $29 \mathrm{Nm}$ \\
\hline Motor rpm required & 1553 \\
\hline Motor power & $4.71 \mathrm{KW}$ \\
\hline
\end{tabular}

components required for assembling a new drive train consisting of electric motor, motor controllers along with electronic throttle, battery management system and battery were identified for the selection procedure.

\section{1)ELECTRIC MOTOR SELECTION}

In considering a suitable electric motor, four major requirements namely high initial torque, high speed, variable load handling capacity and net weight of the motor were considered. With regards to variety of motors, three motor were shortlisted for high torque requirement namely dc series motor, induction motor and bldc motor. The dc series motor has capability of producing high initial torque but at the same time the speed falls drastically at higher torque conditions. The induction motor has capability of self-start but at the same time has low starting torque along withrequirement of advanced control system for dynamic stability. The brushless dc motor (bldc) is a synchronous motor which has rotors with permanent magnets allowing for a high initial torque and lighter weight. Both the induction and bldc may be used but owing to faster response to changing load conditions and lighter weight of the latter, the bldc motor is selected.

\section{2)Battery Pack Selection}

In considering a suitable battery pack three major requirements namely power output, weight and cost were considered for selection. The options available were lithium polymer battery pack and lead acid battery pack. The lead acid battery has heavier weight, high maintenance cost and low initial cost. The lithium polymer based battery pack has capability of fast charging, lighter weight, low maintenance cost and high initial cost. Therefore a lithium polymer based battery pack offers more advantage in comparison hence LiPo battery is selected.

\section{B. Bldc motor simulation results}

After necessary power requirement have been calculated for the bldc motor, the mathematical equations governing the bldc are used for formulation of simulink model fig. 3 and the results for the same are shown in fig.4, fig.5 and fig.6.The basic modelling of bldc drive is further extension from the mathematical models [9][10].The fig.3 is the final system used for simulation of the bldc motor.

The bldc motor under rated load torque of $30 \mathrm{Nm}$ with three different frequencies $50 \mathrm{~Hz}, 35 \mathrm{~Hz}$ and $20 \mathrm{~Hz}$ from the frequency range of 0 to 100 percent are chosen for the purpose of simulation. The varying frequency represents the throttle input to the motor controller thereby controlling the speed [9].Fig.4 shows the speed profile for these selected frequencies, asthe frequency decreases for the motor at rated 


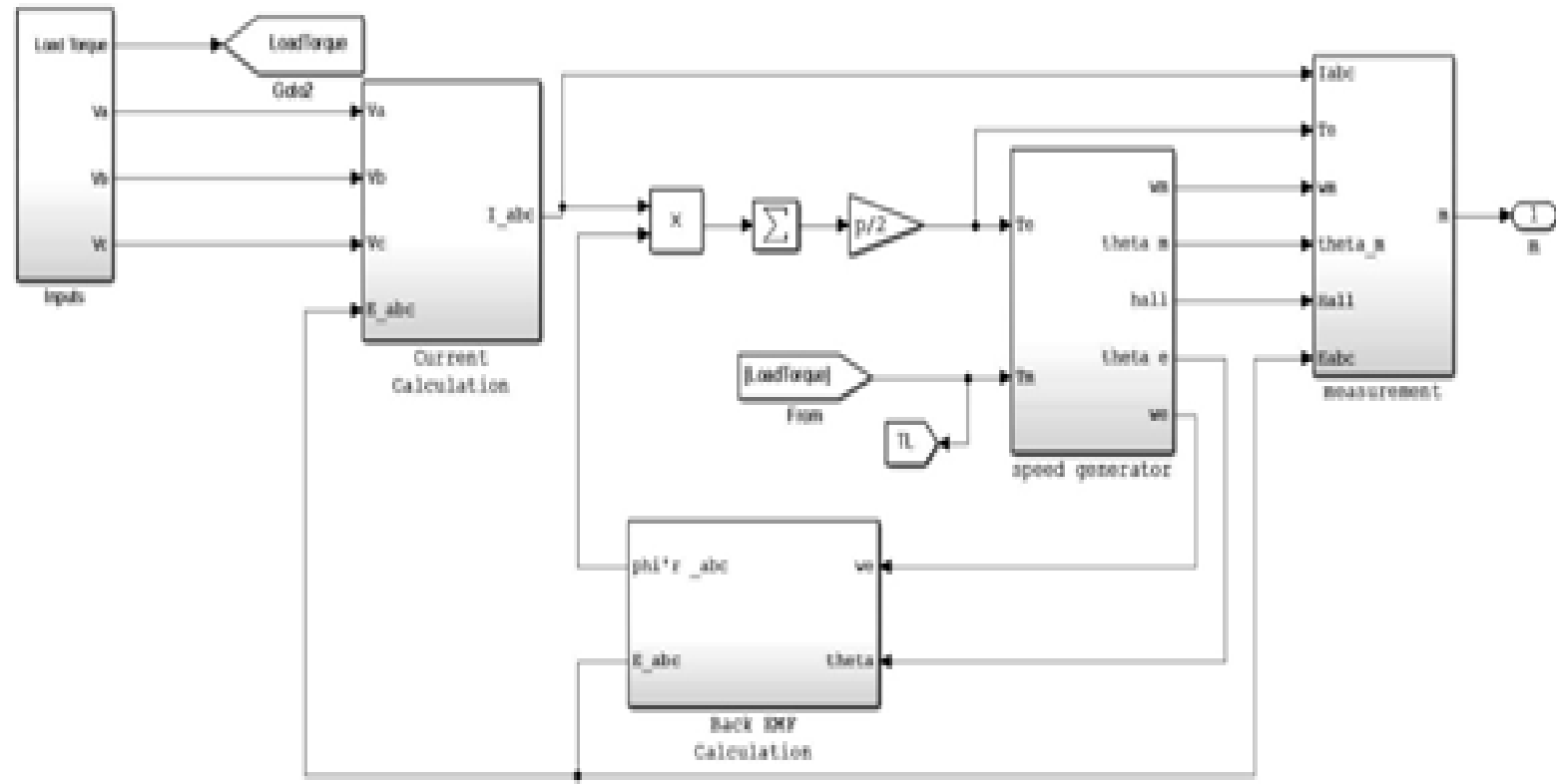

Figure.3. Block diagram of BLDC Simulink model

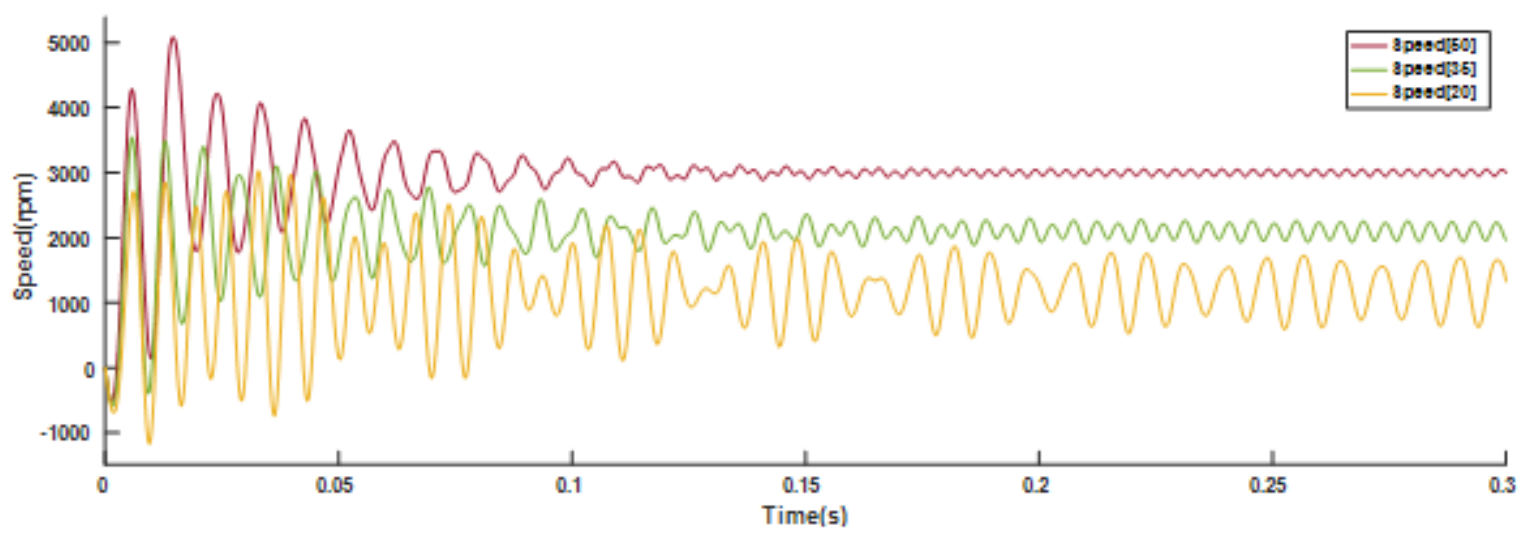

Figure.4. Speed profile of the BLDC motor at frequencies of 50, 35 and $20 \mathrm{~Hz}$ resp. at $30 \mathrm{Nm}$ torque.

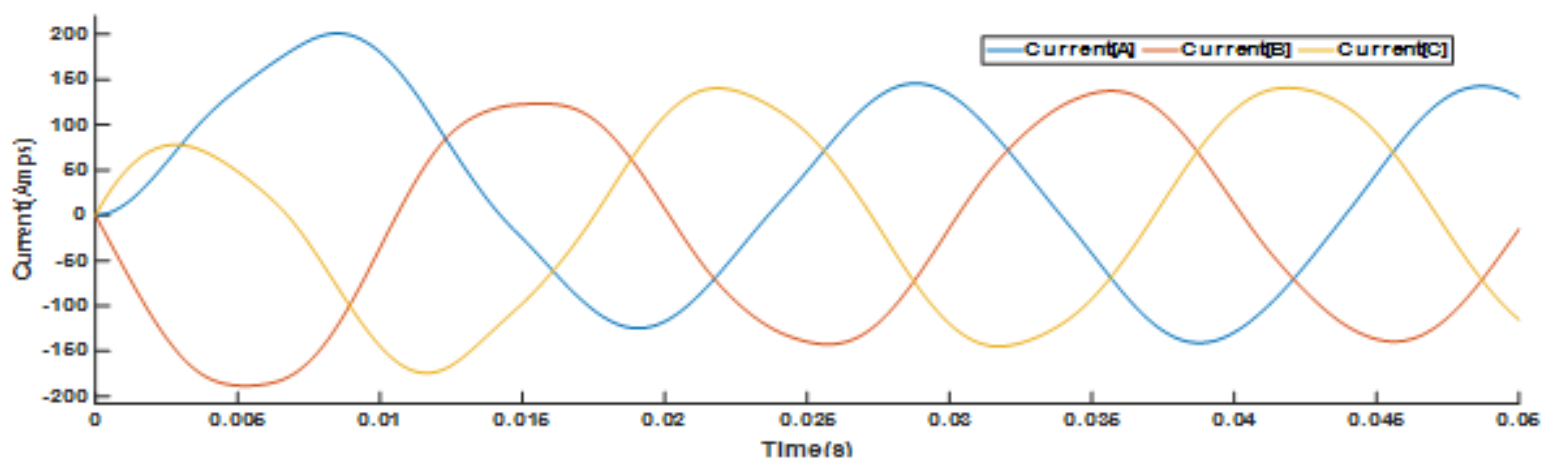

Figure.5. Current profile of the BLDC motor at frequency of $50 \mathrm{~Hz}$ at $30 \mathrm{Nm}$ torque.

load torque,the speed of the motor achieves 3000, 2060 and $1181 \mathrm{rpm}$, which are visible to be decreasing with respect to the frequencies. Hence a higher controllability for the motor's speed range is achieved. The current profile fig. 5 depicts a maximum current of 144A for the ratedload torque with frequency $50 \mathrm{~Hz}$. The maximum current limitis taken in consideration for the selection of wire gauge for the main

tractive system and safety component. In Fig.6 back emf profiles corresponding to the chosen frequencies is shown. As the frequency decreases distortion in the back emf increases for rated load torque and a voltage of $72 \mathrm{~V}$.

Published By: 


\section{Experimental Electric Retrofitting of an Ice Vehicle with Simulation and Cost Analysis}

The back emf profiles reflect higher stability of torque at higher frequencies than at lower frequencies [11].

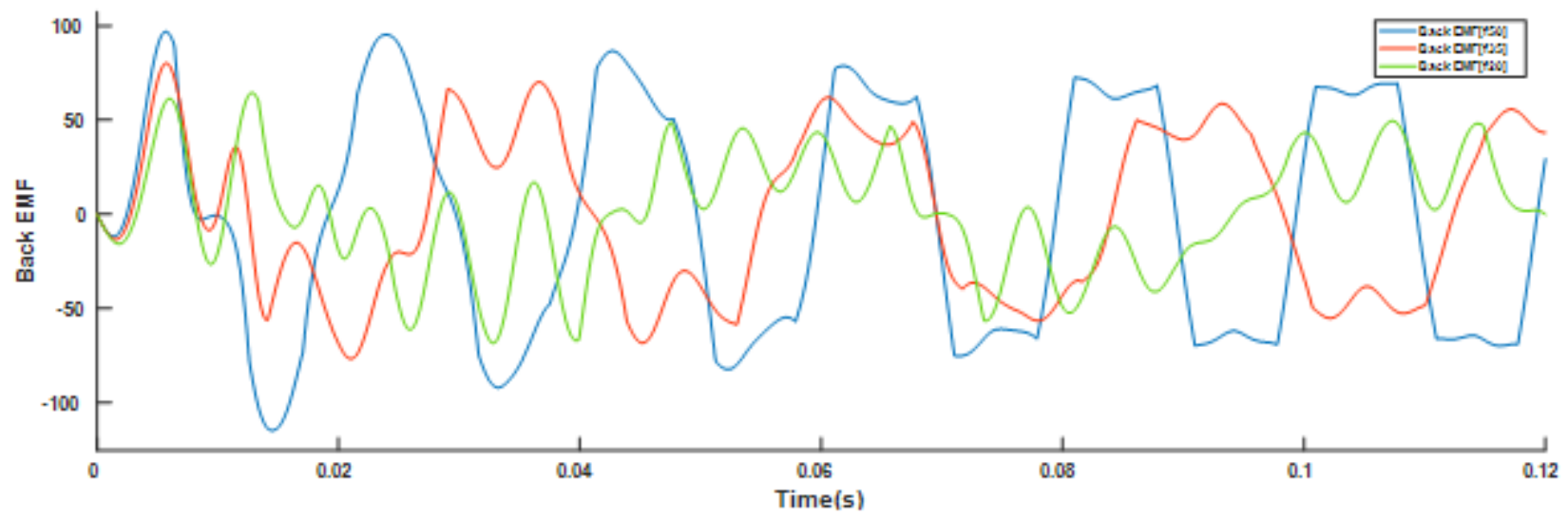

Figure.6. Back EMF profile of the BLDC motor at frequencies of 50,35 and $20 \mathrm{~Hz}$ resp. at $30 \mathrm{Nm}$ torque. torque.

\section{Operational cost comparision of electrical retrofitted} vehicle with ice vehicle

The electric vehicle's cost is compared with ICE vehicle to verify the designed $\mathrm{EV}$ is cost effective and prove the overall process allows for manufacturing of a cost efficient product [12].

Table.3. Initial Parameters for cost calculation

\begin{tabular}{|l|l|l|l|}
\hline Parameters & Petrol & CNG & Electrical \\
\hline $\begin{array}{l}\text { Energy in 1L of } \\
\text { fuel }\end{array}$ & $11 \mathrm{Kwh}$ & $14.6 \mathrm{Kwh}$ & - \\
\hline Efficiency of fuel & 0.2 & 0.42 & 0.8 \\
\hline $\begin{array}{l}\text { Avg distance per } \\
\text { litre of car on fuel }\end{array}$ & $17(\mathrm{~km} / \mathrm{L})$ & $20(\mathrm{~km} / \mathrm{kg})$ & - \\
\hline $\begin{array}{l}\text { Cost of 1L or 1kwh } \\
\text { fuel }\end{array}$ & 74 & 45.2 & 8 \\
\hline $\begin{array}{l}\text { Average Distance } \\
\text { travelled( } \\
\text { Assumed) }\end{array}$ & $18000 \mathrm{~km} / \mathrm{Yr}$ & $18000 \mathrm{~km} / \mathrm{Yr}$ & $18000 \mathrm{~km} / \mathrm{Yr}$ \\
\hline
\end{tabular}

Maintenance cost yearly for petrol and CNG is assumed to be Rs 15000 and Rs 20000 respectively. For EV the installation cost with maintenance is taken as Rs 250000.

Table.4. Final cost calculation

\begin{tabular}{|l|l|l|l|}
\hline & Petrol & CNG & Electrical \\
\hline $\begin{array}{l}\text { Energy } \\
\text { required per } \\
\mathrm{km}\end{array}$ & $\begin{array}{l}0.129 \\
(\mathrm{kwh} / \mathrm{km})\end{array}$ & $\begin{array}{l}0.306 \\
\mathrm{kwh} / \mathrm{km}\end{array}$ & $\begin{array}{l}0.129(\mathrm{kwh} / \\
\mathrm{km})\end{array}$ \\
\hline Running cost & $4.35 \mathrm{Rs} / \mathrm{km}$ & $2.51 \mathrm{Rs} / \mathrm{km}$ & $0.95 \mathrm{Rs} / \mathrm{km}$ \\
\hline $\begin{array}{l}\text { Total } \\
\text { expenses in 5 } \\
\text { yrs }\end{array}$ & Rs 4,66,500 & Rs 3,25,900 & $\begin{array}{l}\text { Rs. } \\
3,35,500\end{array}$ \\
\hline
\end{tabular}

The cost calculations are carried out using initial parameters from Table.3 [12] and cost calculation formula [Appendix 2]. From the above calculation we have conclude that EV is a highly cost effective option in comparison to its ICE counterpart.

\section{EXPERIMENTAL SETUP FOR RETROFITTING PROCESS}

Once the initial stage is completed the retrofitting process started. The following are the steps followed in the retrofitting stage:

1.Initially the fueltank is removed along with exhaust system, the engine, gearbox and then radiator.

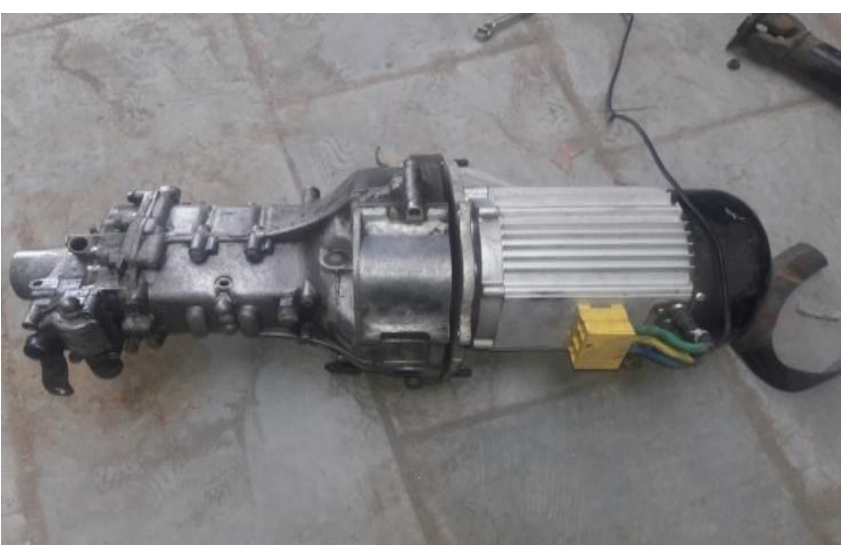

Figure.7. Coupled motor with gearbox

2. To couple the motor an adaptor plate is mounted between the motor and the transmission. After attaching the custom adapter plate we mount the motor using custom mounting brackets.

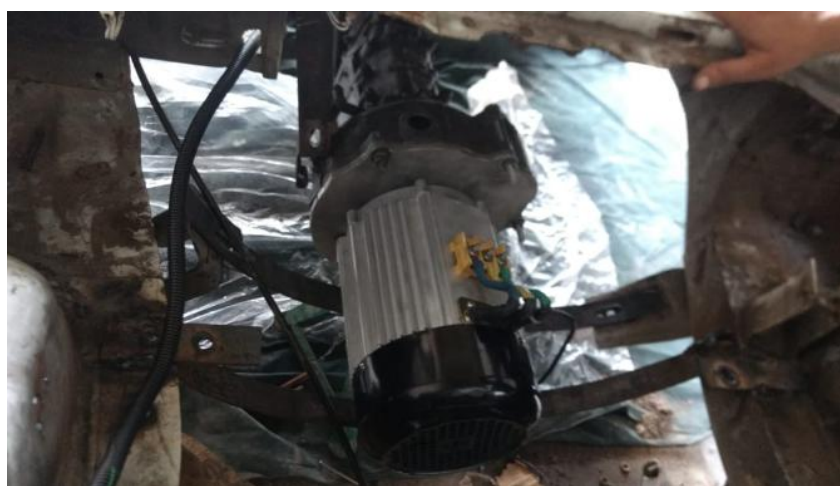

Figure.8. Mounting of motor coupled with gearbox

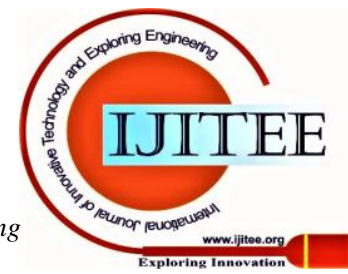


3. The placement of the motor controller is done such that the wire harnesses can be as short as possible.

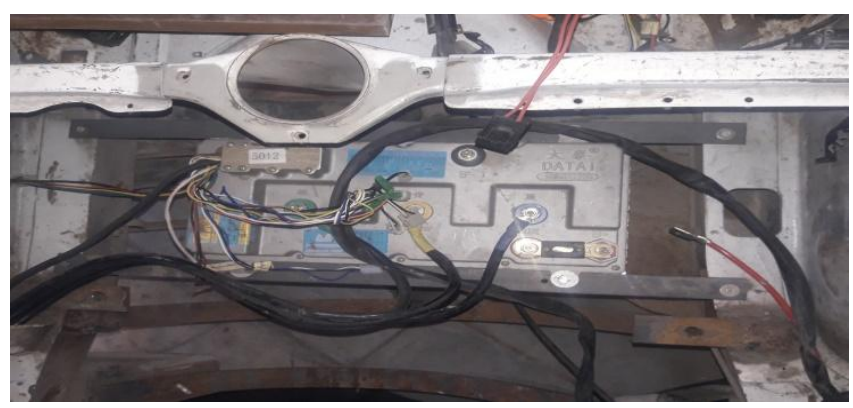

Figure.9. Final placement of motor controller

4. Final assembly of the retrofitted drive along with lithium polymer battery pack.

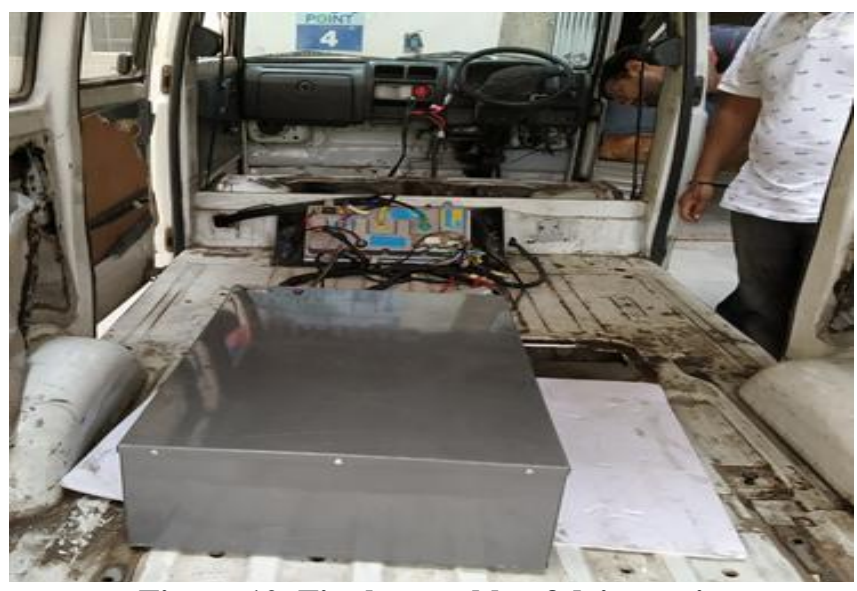

Figure.10. Final assembly of drive train

\section{RESULT AND DISCUSSION}

A carefully generalised method was formed for conversion of any ICE vehicle into an electric vehicle. The motor of higher specification with respect to rpm (motor: $3000 \mathrm{rpm}$ ) was used due to market availability and hence the speed of the vehicle was found higher than desired speed. For cost effectiveness the existing gear box was modified for use. Every single step of the method was carefully evaluated and simulated to ensure high efficiency and cost effectiveness. The maximum speed achieved in initial test run was $46 \mathrm{kmph}$ on a stretch of $3 \mathrm{~km}$ which heated up the tractive system wires. Therefore the wires with gauge corresponding to 1.25 times the maximum current were used as replacement to avoid the heating issue. The final vehicle's weight is within $10 \%$ which is less than limit defined by ARAI for a retrofitted vehicle[13]. The LiPo battery allows for extremely low maintenance cost and reducing the net charge time by great margin with respect to traditional lead acid battery.

\section{CONCLUSION}

Due to fast depletion of fossil fuel sources and increasing pollution levels, the need of the hour is to find and develop an affordable solution which can help tackle the problem. The method devised in this project is one of the many methods that may be employed to current scenarios specifically pertaining to India. The method deploys steps and evaluates selection of optimum equipment ensuring cost as well as energy efficiency with a lower carbon footprint.

\section{APPENDIX 1}

The following calculations are represented via Table(a) where the following notations are used:

$\mathrm{F}_{\mathrm{r}}=$ rolling resistance, $\mathrm{m}=$ mass of body, $\mathrm{a}_{\mathrm{g}}=$ acceleration due to gravity, $c=$ rolling resistance coefficient $F_{D}=d r a g$ force, $\mathrm{A}=$ body area, $\rho=$ density of fluid, $\mathrm{v}=$ flow velocity, $\mathrm{F}_{\mathrm{P}}=$ pulling force, $\mathrm{h}=$ elevation,l=length

\begin{tabular}{|l|l|}
\hline Force & Formula \\
\hline Rolling resistance & $\mathrm{F}_{\mathrm{r}}=\mathrm{c} \mathrm{W}$ \\
\hline Drag force & $\begin{array}{r}\mathrm{F}_{\mathrm{D}}=0.5^{*}\left(\mathrm{c}_{\mathrm{D}} \rho \mathrm{v}^{2} \mathrm{~A}\right) \\
\text { here } \mathrm{A}=2.3 \mathrm{~m}^{2}\end{array}$ \\
\hline $\begin{array}{l}\text { Gradient resistance for } \\
\text { inclined movement }\end{array}$ & $\mathrm{F}_{\mathrm{p}}=\mathrm{W} * \frac{h}{l}=\mathrm{m} \mathrm{a}_{\mathrm{g}} \sin \alpha$ \\
\hline Let $\mathrm{a}^{\circ}=15^{\circ}$
\end{tabular}

\section{APPENDIX 2}

\begin{tabular}{|l|l|}
\hline Parameters & Cost Calculation formulae \\
\hline $\begin{array}{l}\text { Energy required } \\
\text { per kilometer }\end{array}$ & $\begin{array}{l}\text { (energy of 1 } \\
\text { litrefuel)X(efficiency)/(Mileage }(\mathrm{kmpl}))\end{array}$ \\
\hline Running cost & (cost of 1 litre fuel)/(Mileage $(\mathrm{kmpl}))$ \\
\hline $\begin{array}{l}\text { Total expenses in } \\
5 \text { years }\end{array}$ & $\begin{array}{l}\text { (running cost)x(distance travelled in 5 } \\
\text { years })+(\text { maintenance cost of 5 years) }\end{array}$ \\
\hline
\end{tabular}

\section{ACKNOWLEDGEMENT}

We would like to express special thanks of gratitude to our faculties HOD EE Prof. Uma Nangiaand Asst. Prof. Ashish Rajeshwar Kulkarni who gave us this golden opportunity to do this innovative project, which helped us in doing a lot of research and to come across many new facts and developing technologies for the future. We are grateful to have completed this project. This project could not have been completed without the support of HBSS Pvt. Ltd. team consisting of Karnail, Imam, Amaar, Salaam and Sitesh who played a role in experimental setup and Himanshu Bhatnagar(alumni) who sponsored the project.Mechanical couple and motor mounts are subject of further research entitled to team HBSS. Most importantly we would like to express our sincerest gratitude to our faculties whose guidance and constant supervision provided us the necessary information regarding this project.

\section{REFERENCES}

1. Economic Times (2019, Feb 23). Number of vehicles on Delhi roads over 1 crore, with more than 70 lakh two wheelers: Economic survey.EconomicTimes.Retrieved

https://economictimes.indiatimes.com/news/politics-and-nation/numb er-of-vehicles-on-delhi-roads-over-1-crore-with-more-than-70-lakh-t wo-wheelers-economic-survey/articleshow/68128689.cms?from $=\mathrm{mdr}$

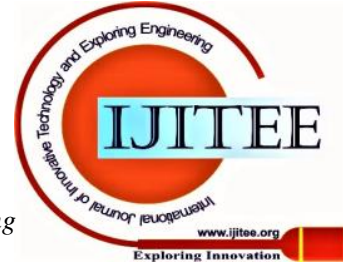




\section{Experimental Electric Retrofitting of an Ice Vehicle with Simulation and Cost Analysis}

2. Yedamale P. Brushless DC (BLDC) motor fundamentals. Microchip Technology Inc. 2003 Jul 28;20:3-15.

3. ZQ Z, Howe D. Comparison of torque-speed characteristics of interior-magnet machines in brushless AC and DC modes for EV/HEV applications. Journal of Asian Electric Vehicles. 2006;4(1):843-50.

4. Mohd TA, Hassan MK, Aziz WM. Mathematical modelling and simulation of an electric vehicle. Journal of Mechanical Engineering andSciences. 2015 Jun 1;8(1):1312-21.

5. VASANTHASEELAN S, DHARUN D, SREERAG S, GOKUL R. CONVERSION OF IC ENGINE VEHICLE TO ELECTRIC VEHICLE.International Research Journal of Engineering and Technology (IRJET).2019 March. Vol 06.

6. Vražić M, Vuljaj D, Pavasović A, Pauković H. Study of a vehicle conversion from internal combustion engine to electric drive. In2014 IEEE International Energy Conference (ENERGYCON) 2014 May 13 (pp. 1544-1548). IEEE.

7. Porselvi, T., Srihariharan, M.K., Ashok, J. and Kumar, S.A., 2017. Selection of power rating of an electric motor for electric vehicles. International Journal of Engineering Science and Computing IJESC, 7(4)

8. Government of India, Ministry of Commerce, Directorate General of Suppliesand Disposals (DGS\&D).Retrieved from: http://dgserver.dgsnd.gov.in/rc/omin_maruti_suzuki_questionnair-.xls .pdf

9. Manali P.Chavhan || PayalA.Shinde, "Modeling of Brushless DC Motor for Electric Vehicle Application", IOSR Journal of Engineering (IOSRJEN), 2019 May, 2278-8719.

10. Jambulingam V. Mathematical Modelling and Simulation of Brushless DC Motor Using Matlab. IJRASET. 2015;3:411-8.

11. Pillay, P. and Krishnan, R., 1989. Modeling, simulation, and analysis of permanent-magnet motor drives. I. The permanent-magnet synchronous motor drive. IEEE Transactions on industry applications, 25(2), pp.265-273.

12. Gujarathi, P.K., Shah, V.A. and Lokhande, M.M., 2018. Cost Analysis for Conversion of Conventional Vehicle into Plug-In Hybrid Electric Vehicle. Journal of Green Engineering, 8(4), pp.497-518.

13. Government of India, Department of Road Transport\& Highways (2017). CMVR Type Approval of VehiclesRetrofitted with Hybrid Electric_system(ARAI-AIS-123). Retrieved from: https://emobility.araiindia.com/wp-content/uploads/2018/06/AIS-123 _and_amd_1.pdf

14. Leitman S. Build your own plug-in hybrid electric vehicle. McGraw Hill Professional; 2009 Sep 7.

15. Keoun BC. Designing an electric vehicle conversion. InProceedings of Southcon'95 1995 Mar 7 (pp. 303-308). IEEE.

16. Pedrosa D, Monteiro V, Gonçalves H, Martins JS, Afonso JL. A case study on the conversion of an internal combustion engine vehicle into anelectric vehicle. In2014 IEEE Vehicle Power and Propulsion Conference (VPPC) 2014 Oct 27 (pp. 1-5). IEEE.

\section{AUTHORS PROFILE}

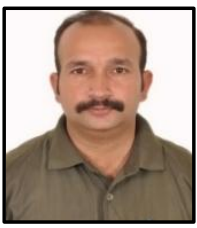

Assistant Professor Ashish Rajeshwar Kulkarni,M.E (Electrical - Control Systems), Electrical Department, Delhi Technological University

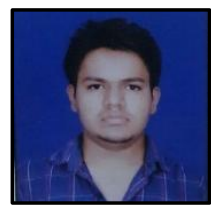

Sudhanshu Singh, Final Year B.Tech, Electrica Engineering Department, Delhi Technological University

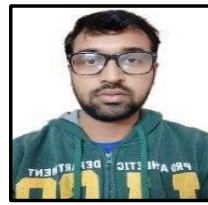

Krishan Kant, Final Year B.Tech, Electrica Engineering Department, Delhi Technological University

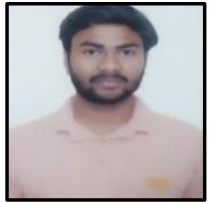

Hemant Bharti, Final Year B.Tech, Electrical Engineering Department, Delhi Technological University 